\title{
Suriye Halep, Hama ve Rakka Müzelerindeki Türk-İslam Dönemine Ait Eserlerden Örnekler
}

\author{
Sample Works from the Turkish-Islamic Era in the Museums of Aleppo, Hama, and \\ Rakka of Syria
}

Razan Aykaç* ${ }^{*}$

Öz

Suriye, dünya tarihi açısından sanatın ve mimarinin en güzel eserlerine sahiptir. İlk Çağ'dan itibaren Palmyra, Afemia, Halep, Şam, Hama, Hums, Bosra, Lazkiye ve Tartus çeşitli medeniyetlere ev sahipliği yapmış önemli yerleşim yerleridir. Bölgede yapılan kazı ve araştırmalarda çıkan buluntular başta olmak üzere pek çok tarihî eser Şam, Halep, Hama ve Rakka müzelerinde sergilenmektedir. Halep müzesinde başta mihrap olmak üzere diğer eserler ile Hama'daki minber ve Rakka Ulu Cami alçı süslemeleri Selçuklular, Zengiler, Eyyûbîler ve Memlükler dönemine ait kıymetli eserlerdir.

Bu makalede Halep, Hama ve Rakka müzelerinde 2011 yılında başlayan iç savaştan önce incelenebilen eserler ele alınmıştır. Yapıldıkları dönemlerin nadide örneklerini oluşturan Halep Müzesi’nden Hüseyin b. Hasan el- Şükri'nin Sandukası, Aslan Kabartmalı Mimari Plastik, Haleviye Medresesi Mihrabı, Güneş Motifli Lüster Kâse, Seamik Kaplar, Memlüklü Armalı Mimari Plastik, Sultan Kayıtbay'a Ait Kitabe Parçası, Savaş Aletleri; Hama Müzesi'nden Hama Ulu Cami Minberi; Rakka Müzesi'nden Rakka Ulu Camisi Alçı Süsleme Parçaları makalede incelenen eserlerdir.

\section{Anahtar Kelimeler}

Suriye, Memlûk /Memlükler, Rakka, Seramik, Alçı Süsleme

\begin{abstract}
Syria has the most beautiful works of art and architecture in world history. Palmyra, Apamea, Aleppo, Damascus, Hama, Homs, Bosra, Latakia and Tartus have been important settlements in the history of civilization since the First Age. Many historical artefacts especially the findings from excavations and research in the region, are exhibited in the museums of Damascus, Aleppo, Hama, and Raqqa. In this article, the works that could be exhibited in the museums of Aleppo, Hama, and Raqqa in the pre-war period (before 2011) are reviewed. The sarcophagus of Huseyin b. Hasan al-Shukri, architectural plastic with lion relief, the mihrab of the Madrasa Halawiye, sun patterned luster bowl, ceramic pots, architectural plastic with Mamluk coat of arms, inscription piece of Sultan Kayıtbay and war tools from the National Museum of Aleppo; the minbar of the Great Mosque of Hama from the Hama Museum and plaster decorations of the Great Mosque of Raqqa from the Raqqa Museum will be introduced. These artefacts are among the most precious examples of their era. The mihrab, especially, and the other works in the National Museum of Aleppo, the minbar in the Hama Museum, and plaster decorations of the Great Mosque Raqqa are very precious works of the Seljuk, Zengid, Ayyubid, and Mamluk eras.
\end{abstract}

\section{Keywords}

Syria, Mamluk / Mamluks, Raqqa, Ceramic, Plaster Decoration

* Sorumlu Yazar: Razan Aykaç (Dr. Öğr. Üyesi), İzmir Kâtip Çelebi Üniversitesi, Sanat ve Tasarım Fakültesi, Temel Sanat Eğitimi Bölümü, İzmir, Türkiye. E-posta: razan.aykac@ikc.edu.tr ORCID: 0000-0002-3267-1218

Atf: Aykac, Razan. "Suriye Halep, Hama ve Rakka Müzelerindeki Türk-İslam Dönemine Ait Eserlerden Örnekler." Art-Sanat, 17(2022): 59-82. https://doi.org/10.26650/artsanat.2022.17.891689 


\section{Extended Summary}

Most of the artefacts-exhibited in the Museum of Aleppo have been extracted from archaeological sites in the north of the country. In the museum, there are works from all historical periods including prehistoric, Ancient Near East, Greek, Roman, Byzantine, and Islamic art. The largest sections of the museum are devoted to the Iron Age and the Islamic period. In the Islamic art section, there are works of pottery, ceramics, metalwork, wood, stone, glass, gold, and silver coins belonging to the Umayyad, Abbasid, Zengid, Ayyubid, Mamluk, and Ottoman eras. According to the data of the Syrian Ministry of Tourism, there are more than 50,000 artefacts in the Museum of Aleppo and its warehouses. The museum and artefacts were damaged when the museum was bombed in 2016. On October 24, 2019, with the support of the United Nations Development Program and the Japanese government, the museum was restored and reopened to visitors.

Sarcophagus of Huseyin b. Hasan al-Shukri reflects the characteristics of the Seljuk period in terms of decoration. The tradition of making cist graves (sarcophagus) in Aleppo continued until the end of the Ottoman period, and there are many similar tombstones from the Ottoman period in the graveyard of the Aleppo Mevlevi Lodge. It is possible to see similar examples of the confronted-lions relief, which was brought from the outer castle walls of Aleppo, in the Citadel of Aleppo, Citadel of Damascus, Madiq Castle, and Diyarbakır Fortress.

The mihrab of the Madrasa Halawiye, built by a woodmaster from Harran in 1245 (AH 643) for the Ayyubid sultan, is the most precious work of the museum. The frame, which turns the mihrab from three directions, has five borders. The outermost border is surrounded by a belt consisting of verses from An-Nur Surah in the celi sulus calligraphy. The second border is decorated with fluting mouldings and the rest with interlocking Rumi patterns. The first border of the Zengid knot is decorated with patterns, the second border with celi sulus calligraphy, and the inner surface with geometric motifs. The semicircular mihrab niche is bordered from below and above, and its surface is geometrically decorated with an eight-armed star. The mihrab, which constitutes the best example of wooden mihrabs, reflects the Seljuk tradition with its celi sulus calligraphy, Zengid-knotted pediment, and floral and geometrical ornaments.

The bowl found in Qal'at Ja'bar excavation belongs to the Ayyubid era. The sun depiction in the center of the ceramic which is decorated in the luster technique with gold luster in the Museum of Aleppo has moon-faced and almond-eyed figures in Uyghur style and reflects the Central Asian interaction. Both the application of this special technique and the composition on it indicate that this work is a custom product. In the Museum of Aleppo, works such as ceramic plates, bowls, jugs, water bottles made in single color glaze, underglaze, or luster techniques are exhibited in the 
showcase. Among them, the ceremonial vessel which is connected from the mouth to the body is a multi-handled, open-form ceramic sample, and glazed in solid turquoise color. Solid turquoise color-glazed- Type-1a. (the flat ellipse bodied) and Type-1b.2 (the oblate globe bodied - with wick holes more than two) oil lambs are also exhibited. Similar lamps can be found in many excavations in Anatolia. Considering the form, technique, and glaze color of the ceremonial vessel and ceramic oil lamps, reflections of the 13th-century Seljuk era can be seen.

Both the coat of arms relief from the Mamluk era and the medallion-shaped inscription piece belongs to the outer castle walls of Aleppo, most of which have not survived. Similar examples of inscription and coat of arms can be seen in the Citadel of Damascus, Gaziantep Castle, and the inscription pieces of Urfa Castle exhibited in the garden of the Ethnography Museum of Ankara. Military-origin Mamluks gave special importance to war tools and armours. Although the decorations on these war tools vary in detail according to the sultans and commanders, they generally include ornaments and prayer inscriptions on the helmets, armours, shields, and maces.

The minbar of the Great Mosque of Hama exhibited in the museum of Hama is one of the two minbars built by Nur ad-Din Zengi in 1174 (AH 569). The second one was built for Al-Aqsa Mosque. The interior of the minbar has geometric ornaments developed from rhombuses in the cagework technique. The gateway section has a horseshoe arch and the kiosk railing on it is divided into two parts. The kiosk section is in the form of a three-segmented arch and the interior of the arches is enlivened by great and small palmette hills. The arch corner and frame of the kiosk have floral decorations with interlocking Rumi patterns. It is one of the most beautiful examples of minbars in the kundekari technique of the Zengid era.

The building, which was built by the Ottoman Empire in 1861 as the Government Office, was opened as the Museum of Raqqa in 1981. Many artefacts in the museum were stolen and destroyed by terrorists during the Syrian civil war. After October 2017, the building started to be repaired, and after 2018, the remaining works in the museum are tried to be preserved. The plaster decorations in the Raqqa Museum, brought from the Great Mosque of Raqqa, are among the most precious examples seen in the region. Similar examples of these plaster decorations reflecting the ornamentation features of the Zengid era are the ones of the Great Mosque of Van, dated to the Seljuk era, and exhibited in the Van Museum.

Hundreds of artefacts from the Turkish-Islamic era are exhibited in the museums of Aleppo, Hama, and Raqqa. In the article, the sarcophagus of Huseyin b. Hasan al-Shukri, architectural plastic with lion relief, the mihrab of the Madrasa Halawiye, sun patterned luster bowl, ceramic pots, architectural plastic with Mamluk coat of arms, inscription piece from the Mamluk era, and war tools from the National Mu- 
seum of Aleppo; the minbar of the Great Mosque of Hama from the Hama Museum and plaster decorations of the Great Mosque of Raqqa from the Raqqa Museum are reviewed. These artefacts are among the most precious examples of their no need era. The mihrab, especially, and the other works in the National Museum of Aleppo, the minbar in the Hama Museum, and plaster decorations of the Great Mosque Raqqa are very precious works of the Seljuk, Zengid, Ayyubid, and Mamluk eras. 


\section{Giriş}

Stratejik konumu ve iklimi sebebiyle İlk Çağ'dan itibaren medeniyet tarihinin önemli yerleşim yerleri Suriye'de kurulmuştur. Özellikle Palmyra, Afemia, Halep, Şam, Hama, Hums, Bosra, Lazkiye ve Tartus bölgedeki önemli yerleşim yerleridir ${ }^{1}$. Tarihin her döneminde önemli medeniyet merkezlerini barındıran Suriye dolayısıyla dünya tarihi açısından sanatın ve mimarinin önemli eserlerine sahiptir. Bölgede yapılan kazı ve araştırmalarda çıkan eserler başta olmak üzere pek çok sanat eseri Şam, Halep, Hama ve Rakka müzelerinde sergilenmektedir. Bu çalışma kapsamında Halep, Hama ve Rakka müzelerindeki çeşitli eserlerin fotoğrafları çekilmiş, kitabe okumaları yapılmış ve eserler hakkında bilgi verilmiştir.

\section{Halep Müzesi}

Halep şehrindeki müze 1928 yılında kurulmaya başlamış ve resmi olarak küçük bir Osmanlı saray binasında 1931'de açılmıştır. Bu müze ihtiyacı karşılayamadığı için günümüzdeki binası inşa edilerek 1972'de müze yeni yerine taşınmıştır. Müzede sergilenen eserlerin çoğu ülkenin kuzeyindeki arkeolojik alandan çıkarılmıştır. 2016'da müze bombalanmış ve müze ile müzedeki eserler hasar görmüştür. 24 Ekim 2019'da Birleşmiş Milletler Teşkilatının Kalkınma Programı ve Japonya Hükümeti'nin desteğiyle müze restore edilerek yeniden ziyarete açılmıştır. Ancak müzedeki eserlerin mevcut durumlarıyla ilgili savaş devam ettiğinden sağlıklı bilgi alınamamaktadır.

Müzede Tarih Öncesi, Antik Yakın Doğu, Yunan, Roma ve Bizans ile İslam dönemine ait bölümler ve bu dönemlere ait eserler bulunmaktadır. Müzenin en büyük bölümü Demir Çağ ve İslam Dönemi için ayrılmıştır. İslam Sanatı bölümündeki sergileme İslam hanedanlarına ait çanak çömlek, seramik, metal işi ve cam malzemeden eserlere dayanmaktadır. Ayrıca Emeviler, Abbasiler, Zengiler, Eyyûbîler, Memlükler ve Osmanlılar dönemlerine ait altın ve gümüş sikkelerinden oluşan bir koleksiyon İslam dönemi bölümde yerini almıştır. Üzeri çiçekli kufi hat ile bezeli sanduka bu salonun en önemli parçasını oluşturmaktadır. Ayrıca Haleviye Medresesi’nin ahşap mihrabı müzenin önemli eserleri arasındadır. Orta Çağ askeri teçhizatı ve bir yan odadaki Osmanlı ahşap tavanı da sergilenen eserler arasındadır.

\subsection{Hüseyin b. Hasan el- Şükri’nin Sandukası}

Eser, Halep'in en eski yerleşim yeri olan ve İbrahim Peygamber ile bağlantılı kutsal bir yapı olan Makam İbrahim'in etrafında oluşturulan şehrin güneyindeki Salih Mezarlığı'ndan getirilmiştir. Sanduka, Zengiler döneminde yaşamış Hüseyin b. Hasan

1 Abdüsselâm Uluçam, "Suriye Mimari", TDV İslâm Ansiklopedisi, c. 37 (İstanbul: Türkiye Diyanet Vakfı Yayınları, 2009), 559-565; Abdülkâdir Er- Reyhâvî, El I'mâratü'l Arabiyyetü'l İslâmiyye, Hasâisuhâ ve Âsâruhâ fí Suriye (Dımaşk: 1999), 27-28; Max Van Berchem, Materiaux pour un Corpus Inscriptionum Arabicarum, XLV (Kahire: Fransız Arkeoloji Enstitüsü Yayınlar1, 1920-1923), 78; Julia Gonnella, Das Aleppo Zimmer im Museum für İslamische Kunst (Berlin: Museum für İslamische Kunst, 1996), 11. 
el- Şükri'ye ait olup müzede 330 envanter numarasıyla kayıtlıdır ve 98 x $190 \mathrm{~cm}$ ebatlarındadır. Taş malzemeden olan sandukanın kaide kısmında düğüm motifi dört tarafı dolamaktadır. Gövdede çiçekli kufi hatlı Ayetel Kürsi kabartma tekniğinde hakkedilmiştir. Üstteki oval sanduka kapağı ise sade tutulmuştur (G. 1).

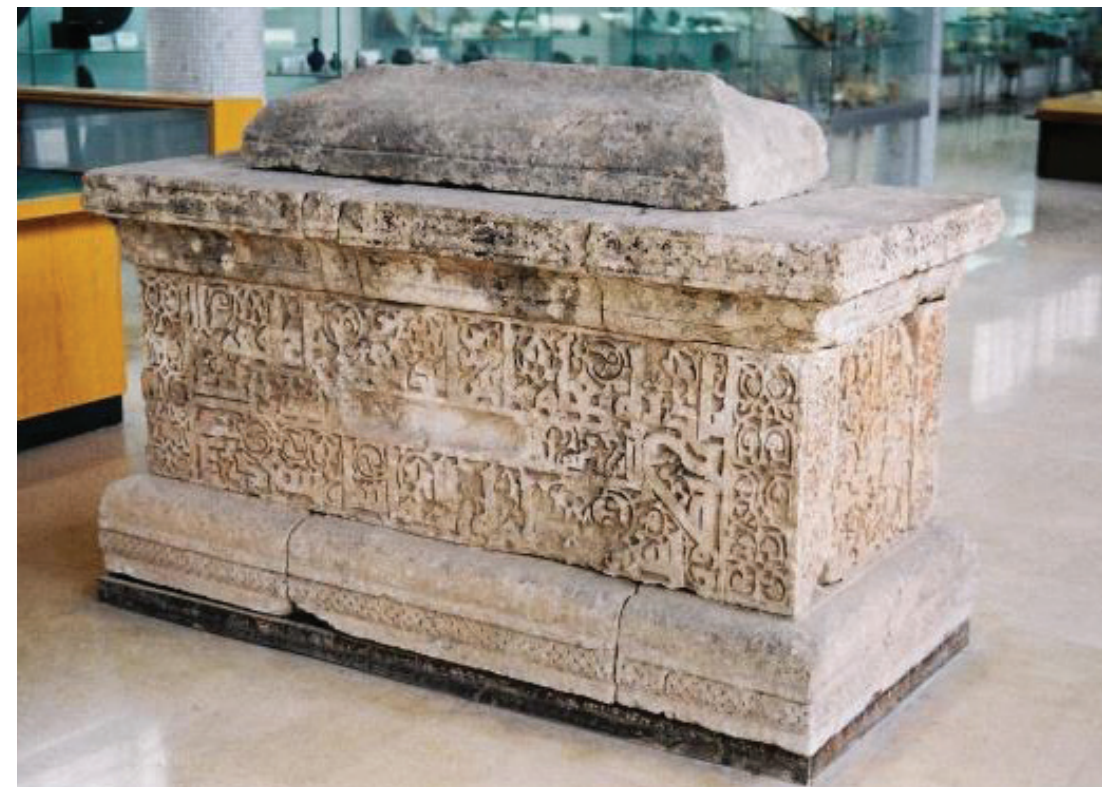

G. 1: Halep Müzesi Hüseyin b. Hasan el- Şükri'nin Sandukası (R. Aykaç, 2007)

\subsection{Aslan Kabartmalı Mimari Plastik}

Halep şehrinin etrafını kuşatan surlar üzerinde ve surlarda yer alan kapılarda aslan kabartmaları bulunmaktadır. Surlar üzerinde aslan kabartmaları Selçuklular, Zengiler, Eyyûbîler ve Memlükler dönemlerinde görülmektedir. İki taş parçası üzerinde alçak kabartma tekniğinde yapılan karşılıklı iki aslan betimlemesi Halep Kalesi’nin kapılarından getirilmiştir (G. 2). Ancak hangi kapıdan getirildiği bilgisi mevcut değildir. Selçuklu tarzındaki betimlemede baş ve gövde profilden verilmiş olup aslanların boğazlarında zincir bulunmaktadır. 


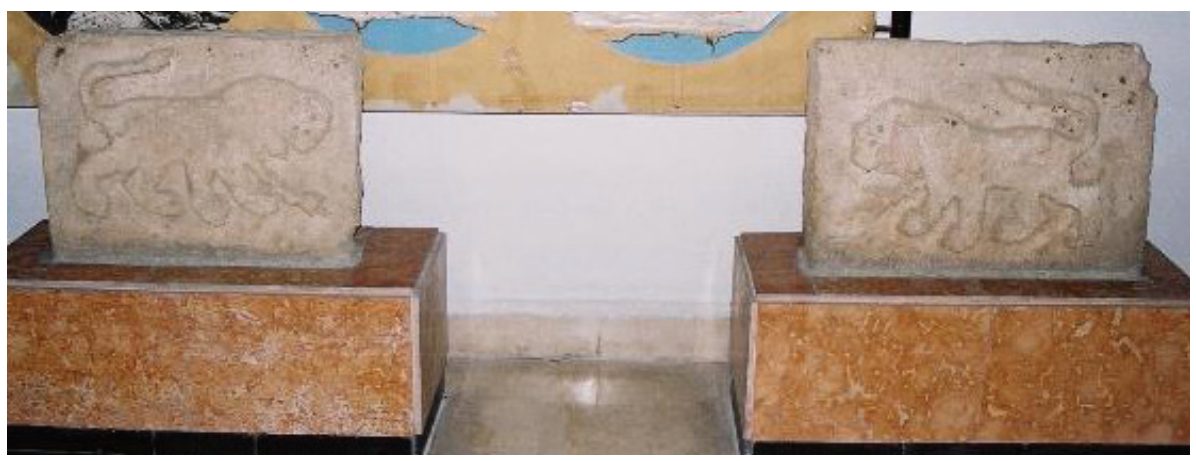

G. 2: Halep Müzesi Aslan Kabartmalı Mimari Plastik (R. Aykaç, 2007)

\section{3. Haleviye Medresesi Mihrabı}

Haleviye medresesi, taç kapısında yer alan kitabeye göre Nureddin Zengi tarafindan H 543/ M 1148 yılında kiliseden medreseye çevrilmiştir. Halep çamından yapılan mihrabı 4.50 m yüksekliğinde ve 3.50 m genişliğindedir. Mihrap Harranlı usta Ebü'lHüseyn Muhammed bin el-Harrani tarafından H 643 / M 1245 senesinde yapılmıştır².

\section{Kitabe Metni:}

بسم الله الرحمن الرحيم أمر بعمله مولانا الملك العادل المجاهد نور الدين ركن الإسلام والمسلمين محيي

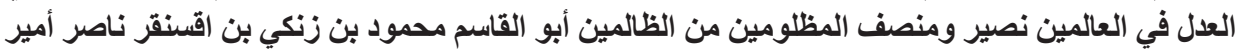
المؤمنين أعز الله أنصاره وضاعف ومئ اقتداره سنة تسع وخمسين وخمسمئة.

\section{Kitabenin Okunuşu:}

Bismillâhirrahmânirrahîm emerâ bi'emelihi Mevlana el-Melik el-Adil el-Mücahid Nureddin Rüknü'l-İslam ve'l-müsellimin Muhyi el-Adil fî el-Alemin Nasir ve munsif el- mazlumin mine'ez-Zâlimin Ebu'l-Kasım Mahmud bin Zengi Bin Aksungur Nâsır Emin el-Mü'min e'azzallâhu ensârehû ve dâ'afe iktidarehû sene tis'a ve hamsiyn ve hamse mâe (H 559 / M 1163-1164).

\section{Türkçe Tercümesi:}

Bismillahirrahmanirrahim efendimiz, adil kral, alperen, dinin nuru, İslam ve Müslümanların rüknü, dünyada adaleti yaşatan, mazlumlara yardımcı olan ve mazlumların zalimlerden haklarını alan, müminlerin emirini destekleyen Ebu el-Kâsim Mahmut bin Zenkî bin Aksangar. Allah onu destekleyenleri aziz kılsın ve onun iktidarını artırsın. Y11 559

Sanatkâr imzası: صنعة أبو الحسين محمد بن الحرّاني رحمه اللها

2 Terry Allen, "Madrasah al- Halâwîyah", In Ayyubid Architecture” (Occidental, CA: Solipsist Press, 2003); "Madrasah al-Hâlawîyah", erişim 2 Ağustos 2005, http://www.sonic.net/ tallen/palmtree/ayyarch/ch2. htm\#alep.mhal; Abdallah Hadjar, Historical Monuments of Aleppo (Aleppo: Automobile and Touring Club of Syria (A.T.C.S), 2000), 25-26. 
İmzanın Okunuşu: Sa'ata Ebü'l-Hüseyn Muhammed Bin el-Harrani Rahmehu allâh

Türkçe Tercümesi: Ebu el-Hasan bin el-Harranî’nin (Allah rahmet eylesin) eseridir.

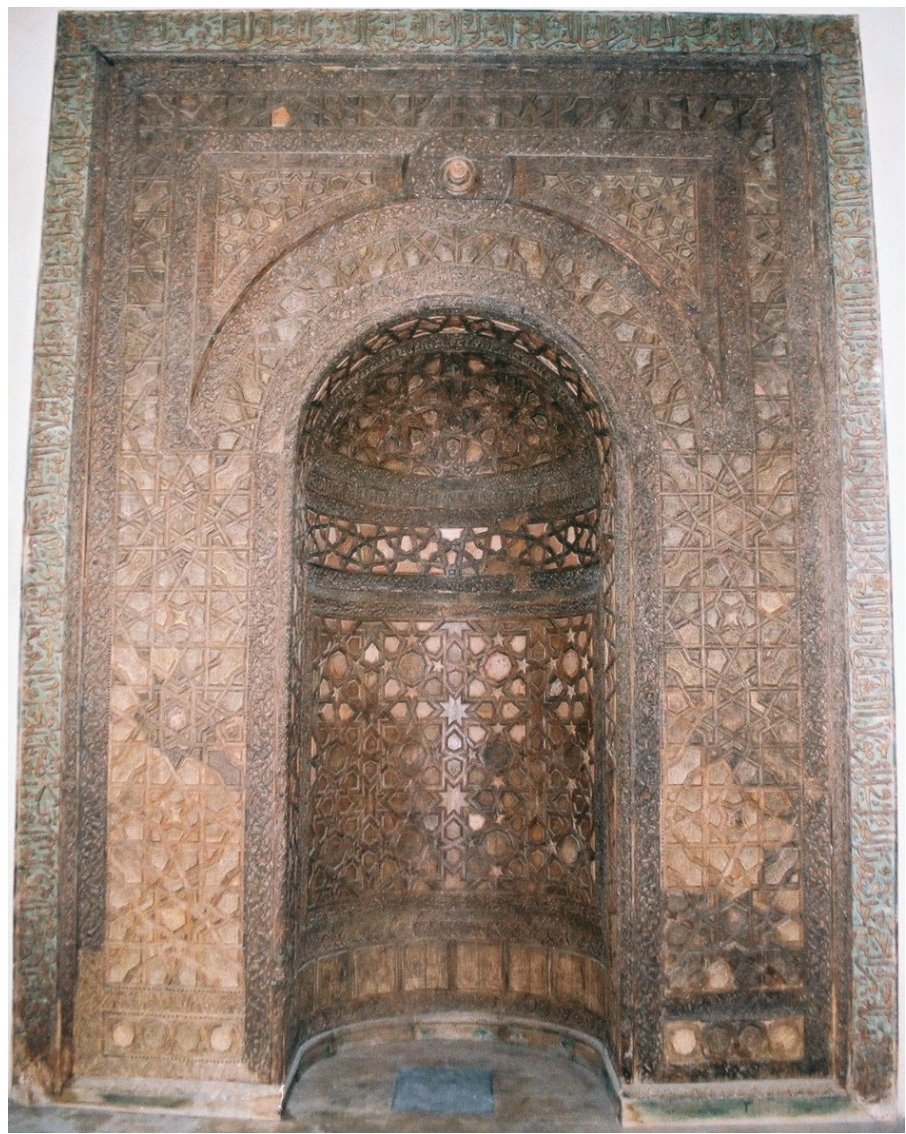

G. 3: Halep Müzesi Haleviye Medresesi Mihrabı (R. Aykaç, 2007)

Mihrabı üç yönden çeviren çerçeve beş bordürlüdür. En dıştaki bordürde celi sülüs hatlı Nur Suresi, ayet-i kerimeden oluşan bir yazı kuşağı ile çevrilidir. İkinci bordür kaval silme, devamı birbirine geçmeli rumi motifiyle tezyin edilmiştir. Yüzeyi kaplayan geniş bordür ise altı kollu yıldızdan gelişen geometrik bezemeli olup iç kısım rumi motifi ile sonlanmaktadır.

Zengi düğümlü alınlığın ortası kabara biçiminde dışa taşıntılıdır . Zengi düğümünün birinci bordürü rumi, ikincisi celi sülüs hatlı yazıyla, iç yüzeyi de geometrik motiflerle tezyin edilmiştir. Yarım daire planlı mihrap nişi alttan ve üstten bordürlerle sınırlandırılmıştır ve mihrap nişinin yüzeyi sekiz kollu yıldızdan gelişen geometrik süslemelidir (G. 3, G. 4, G. 5).

3 Ahmet Vefa Çobanoğlu, "Zengiler (Mimari)”, TDV İslâm Ansiklopedisi, c. 44 (İstanbul: Türkiye Diyanet Vakfi Yayınları, 2009), 272. 


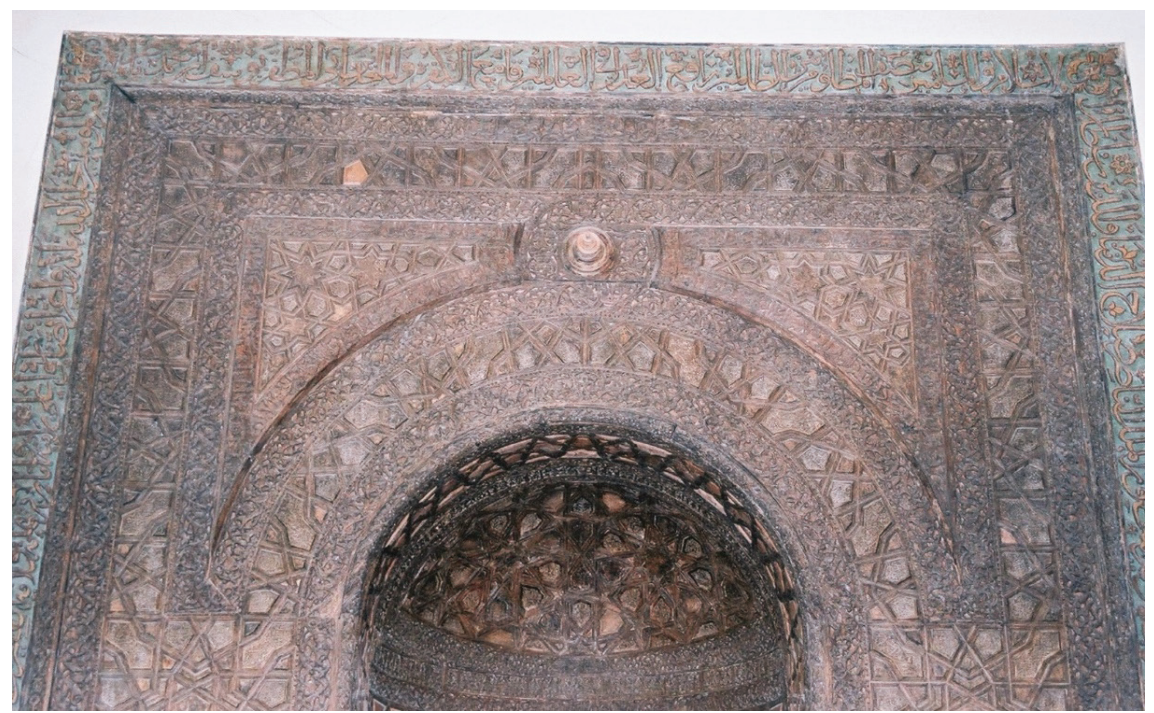

G. 4: Halep Müzesi Haleviye Medresesi Mihrabından ayrıntı (R. Aykaç, 2007)

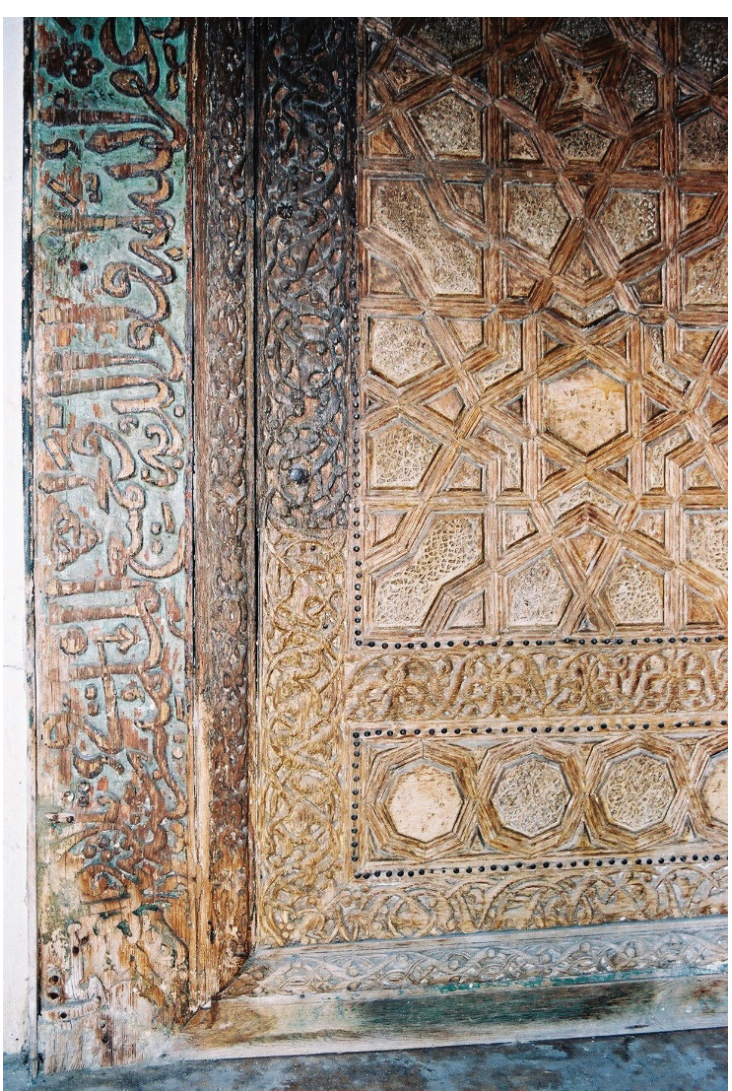

G. 5: Halep Müzesi Haleviye Medresesi Mihrabından ayrıntı (R. Aykaç, 2007) 


\subsection{Güneş Motifli Lüster Kâse}

13. yüzyıl Eyyûbîler dönemine ait kâse Caber Kalesi'ndeki kazılarda çıkarılmıştır. Kâse frit hamurlu, lüster tekniğinde yapılmış, şeffaf sırlı, üzeri koyu kahverenginde dekore edilmiştir. Merkezde bulunan güneş tasviri Uygur-Selçuklu tipinde kadınsı yüz özelliklerine sahiptir. Güneş tasvirinin etrafı, güneşten yayılan ışıllar ve simetrik olarak devam eden dairesel bezemelerle ayrıca bunların arasında yer alan stilize palmet motifleriyle süslüdür. Ağız kenarındaki bordür çift dikey çizgilerle 12 eşit parçaya bölünmüştür ve araları düzenli olarak noktalanan ve eğrisel motiflerle oluşturulmuş soyut bezemelerle süslenmiştir (G. 6).

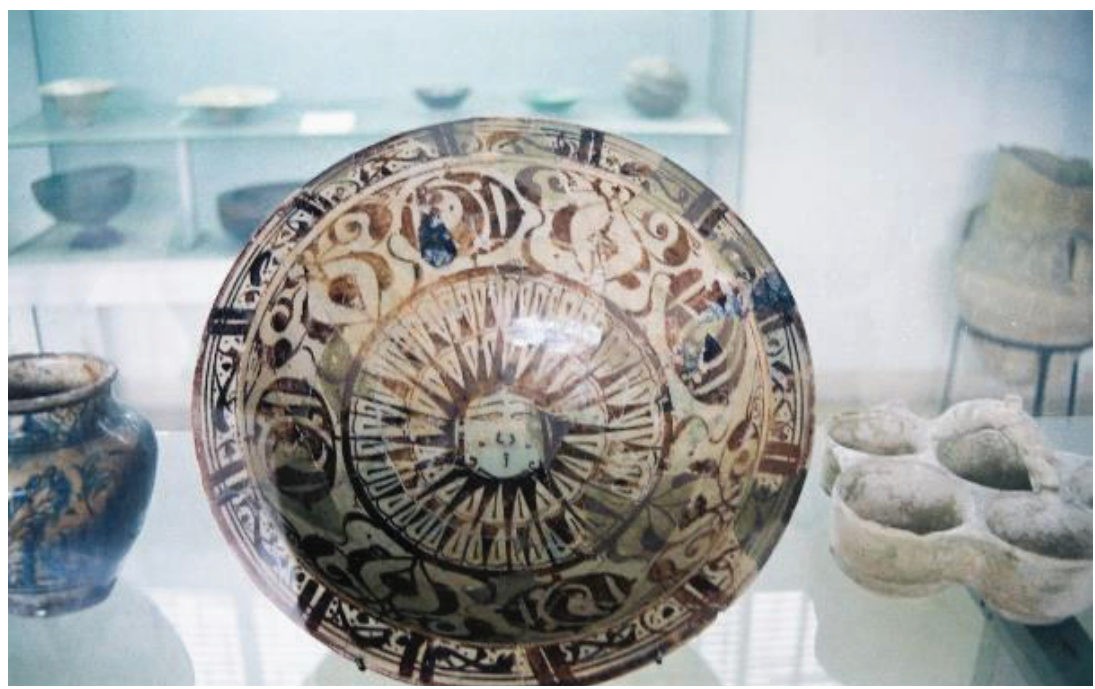

G. 6: Halep Müzesi Güneş Motifli Lüster Kâse (R. Aykaç, 2007)

Burç ve gezegen sembolleri, İslami dönemde özellikle kakma metal işlerinde, daha nadiren de seramiklerde görülmektedir. Orta Çağ Suriye seramiklerine böyle bir tasvirin işlenmesi bu kâsenin önemini vurgulamaktadır. Bunun orijinal dekorlu seramik bir kâsede uygulanması Sultana özel tasarım olmasıyla ilişkilendirilebilir.

\section{5. Seramik Kaplar}

Vitrinde İslami döneme ait farklı ebatlarda ve derinlikte kap kacak, sürahi, kâse, matara, tören $\mathrm{kab}_{1}{ }^{4}$, basık küre gövdeli ve ikiden fazla fitil delikli kandiller ${ }^{5}$, kandillik, testi, vazo, sürahi, şekerlik, küp ve figürinden oluşan eserler sergilenmektedir. $\mathrm{Bu}$ seramikler tek renk sırlı, lüster, sıraltı tekniklerinde ve sgrafitto (kazıma), baskı,

4 Razan Aykaç, Silifke Kalesinin Kazılar Sonucu Ortaya Çıkan Yerleşim Dokusu (İstanbul: Ege Yayınları, 2021), 467.

5 Razan Aykaç, Konya Karatay Müzesindeki Anadolu Selçuklu Dönemi Seramik Kandiller (Konya: Palet Yayınları, 2017), 90, 96, 104; Razan Aykaç, Türkiye Müzelerindeki İslami Dönem Seramik Kandiller (İstanbul: Ege Yayınları, 2021), 217. 
barbutin bezeme yöntemleriyle yapılmış farklı süsleme özelliklerine sahiptir. Eserler vitrine bir gruplama olmaksızın karışık halde yerleştirilmiştir.

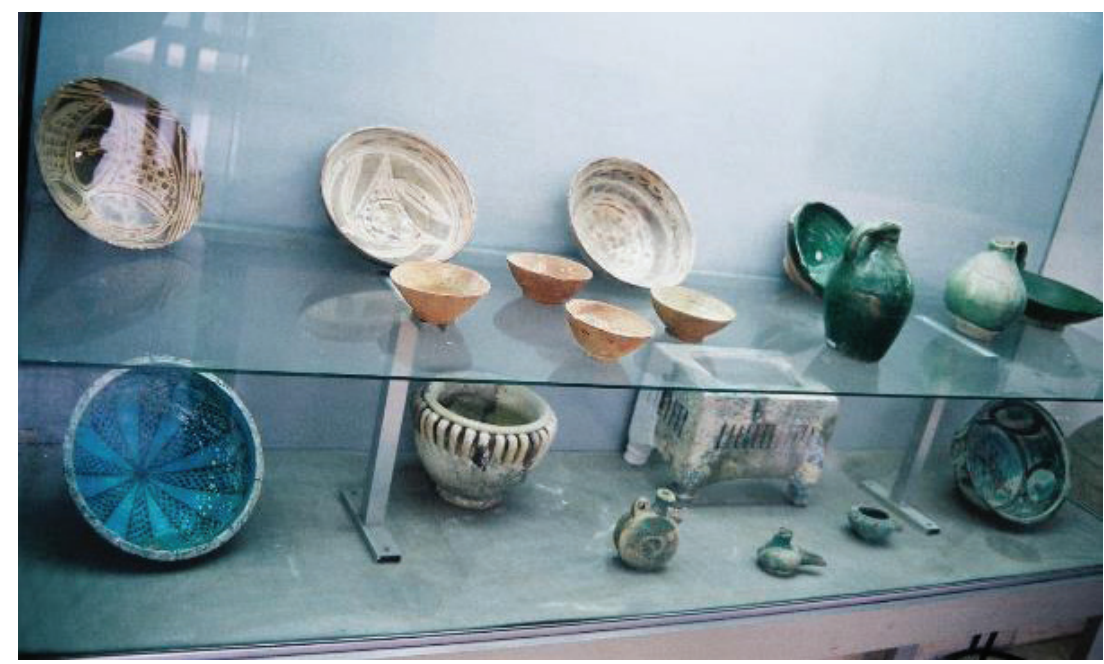

G. 7: Halep Müzesi Seramik Kaplar (R. Aykaç, 2007)

\subsection{Memlüklü Armalı Mimari Plastik}

Halep Müzesindeki bu mimari plastik Memlükler döneminde yönetici, komutan ve soylu kişilerin kullandığı armalardan biridir. Taş malzemeye alçak kabartma tekniğinde yapılan bu arma; daire içinde eşkenar dörtgen ve onun içinde kişiyi simgeleyen iki figür, figürlerin bir tarafında kupa, diğer tarafı zaman içerisinde aşındığından ne olduğu tam anlaşılmayan bir motiften oluşmaktadır. Memlükler dönemine ait anıtsal bir yapıya ait olan bu eser, muhtemelen Halep dış kalesinden getirilmiştir. 


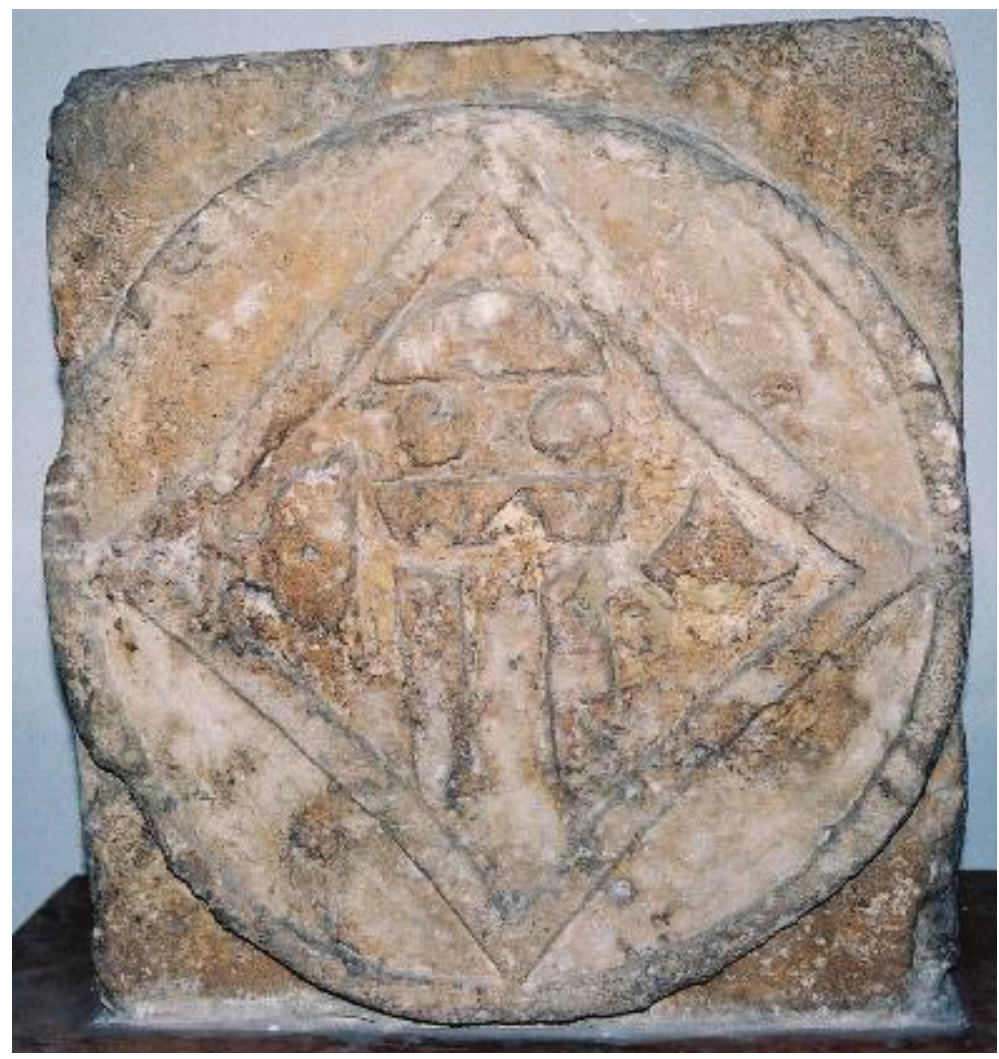

G. 8: Halep Müzesi Memlüklü Armalı Mimari Plastik (R. Aykaç, 2007)

\section{7. Sultan Kayıtbay'a Ait Kitabe Parçası}

Memlük Sultanı Kayıtbay'a (1423-1496) ait olan bu kitabenin envanter kaydı bulunmamaktadır. Kitabede geçen “fetihlerin babası" sıfatından ayrıca Halep Kalesi'ni Sultan Kayıtbay'ın tamir ettirdiği ve eklemeler yaptırdığı bilgilerinden hareketle bu kitabenin Halep Kalesi'nden müzeye taşınmış olduğu söylenebilir. Memlükler döneminde eserler üzerinde bu tarzda bani kitabesi yaygın olarak görülmektedir ${ }^{6}$. Taş malzeme üzerine kabartma tekniğinde, müdevver istifli olarak Arapça yazılan kitabe, celî sülüs hatlıdır.

\section{Kitabe Metni:}

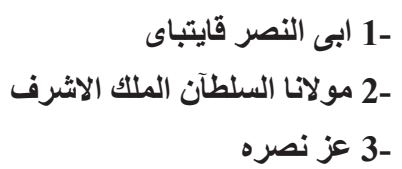

6 Michael Meinecke, Die Mamlukische Architektur in Agypten und Syrien (Glückstadt: Verlag J.J. Augustin, 1992), Tafel 70/a. 


\section{Kitabenin Okunuşu:}

1- Ebi’n-Nasr Kâyıtbây

2- Mevlânâ es-Sultân el-Melîk el-Eşref

3- Azze Nasruhû

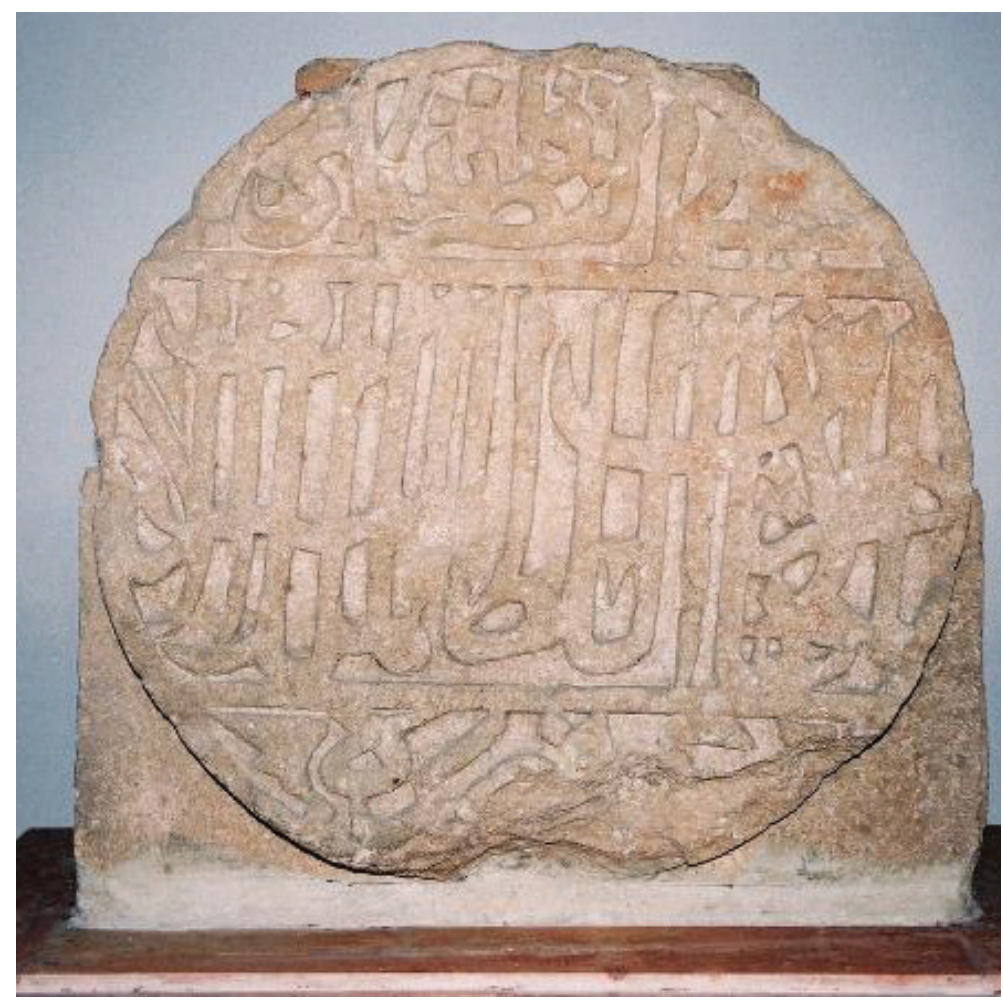

G. 9: Halep Müzesi Sultan Kayıtbay’a Ait Kitabe Parçası (R. Aykaç, 2007)

Sultan Kayıtbay (1423-1496) hükümdarlığı döneminde pek çok eser yaptırmış ya da mevcut eserleri tamir ettirmiştir. Bu kitabe de muhtemelen Halep Kalesi'ndeki kapilardan birine konulan bani kitabesidir.

\section{8. Savaş Aletleri}

Kalkan, miğfer, kılıç, askeri zırh kıyafetlerinden oluşan savaş malzemeleri İslam dönemine ait bölümün vitrininde sergilenmektedir. Savaşlarda ok, kılıç ve diğer öldürücü malzemelerden korunmak için vücudu kaplayan, metal malzemeden yapılmış koruyucu giysiler kullanılmaktaydı. Vitrinde sergilenen eserlerden Memlükler dönemine ait kalkanın ortasında kabartma tekniğinde yapılmış insan yüzü suretinde güneş motifi vardır. Onun altın parıltısı, çevresindeki kazıma tekniğiyle oluşturulan sekiz 1şınsal kol ile simgelenmektedir. Bu 1şınsal kollar Halep Valisi Aydemir Eşrefi'nin ar- 
ması olan "kupa" motifiyle ${ }^{7}$ sonlanmaktadır. Bu motiflerin arasında da çeşitli çizgisel bezemeler yer almaktadır. Ayrıca kalkanın yüzeyinde simetrik olarak yerleştirilmiş, yarım daire şeklinde yüksek dört kabara bulunmaktadır. Diğer kalkanın ortasında kazıma tekniğinde yapılmış bitkisel süslemeler mevcuttur, etrafını ise yazı şeridi dolamaktadır. Üzerinde diğer kalkanda olduğu gibi dört kabara mevcuttur. Miğferlerin yüzeyi bitkisel süslemelidir.

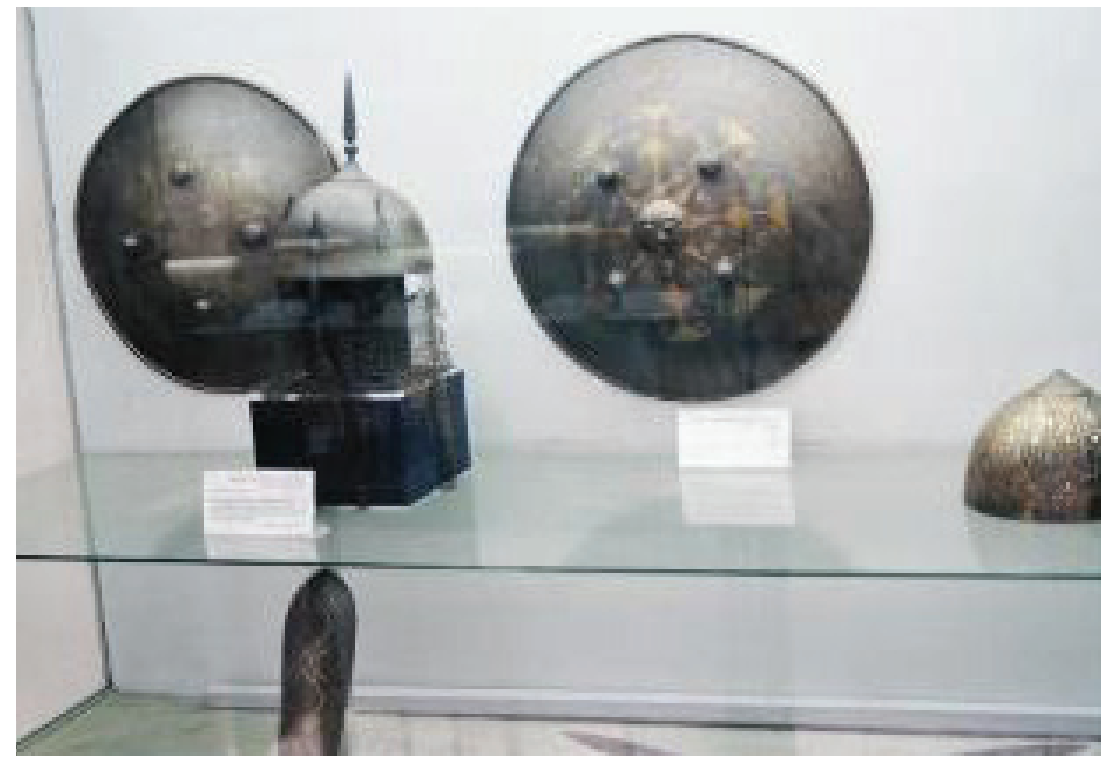

G. 10: Halep Müzesi Savaş Aletleri (R. Aykaç, 2007)

\section{Hama Müzesi}

Bu yeni müze, şehrin 2 km kuzeyinde yer almaktadır. Müze binasına 2006-2008 yılları arasında bir galeri ve bir koruma laboratuvarı eklenmiştir. Müzede arkeolojik kazılardan çıkan Hellenistik, Roma, Bizans ve İslam dönemlerine ait eserler sergilenmektedir. En önemli eserler arasında Hama'daki su çarkı yapısının ${ }^{8}$ ilk görsel örneği olan Noria Mozaiği, Şaduf Kavanozu ve Hama Ulu Cami Minberi bulunmaktadır.

\subsection{Hama Ulu Cami Minberi}

Nurettin Zengi’nin Hama Ulu Camii için Halepli ustaya yaptırdığg ahşap, kündekari tekniğindeki minber H 559 / M 1163-1164 tarihli olup Hama Müzesinde 3266 envanter numarasıyla kayıtlıdır. Yüksekliği $4.25 \mathrm{~cm}$, genişliği $3.20 \mathrm{~cm}$, eni $84 \mathrm{~cm}$

7 Güner İnal, Türk İslam Maden Sanatı (Ankara: Hacettepe Üniversitesi-Teksir Bask1, t.y), 34; David Storm Rice, "Studies in Islamic Metal Work", Bulletin of the School of Oriental and African Studies 14 (1952), 576.

8 Ali Boran, "Hama’daki Tarihi Su Dolapları ve Kemerler”, Su Medeniyeti Sempozyumu (Konya: Büyükşehir Belediyesi, 2010), 502-515. 
ebatlarındaki minber orta boy minberler grubu içerisinde değerlendirilmektedir. Giriş söveleri ile sınırlanmış minberin merdiven korkulukları celi sülüs hat ile yazılı Kelime-i Tevhit ve kitabe kuşağıyla çevrilidir. Sağ korkulukta orijinal kitabe yer almaktadir.

\section{Kitabe Metni:}

بسم الله الرحمن الرحيم جدد هذا المحراب في أيام مولانا السلطان الملك العادل المخلص المرابط المؤيد

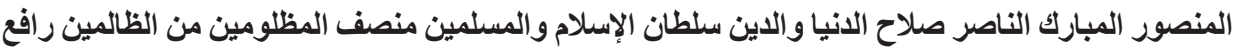

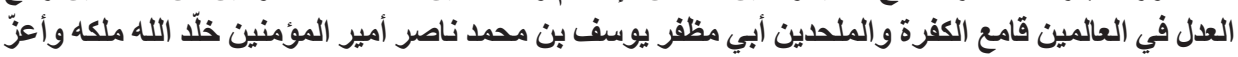

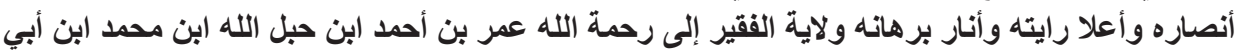

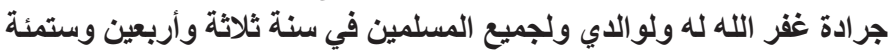

\section{Kitabenin Okunuşu:}

Bismillâhirrahmânirrahîm cedde haze el-Mihrab fi eyam Mevlâna es-Sultan elMelik el-Adil el-Muhlis el-murabit el-mü' eyyed el-Mansûr el-Mübarek en-Nâsır Salâh ed-Dünya ve'ddîn Sultanü'l-İslâm ve'l-Müsellimin munsıf El-Mazlûmin mine'ez-Zalimin rafi el-Adil fî el-Alemin Kâmi' el-Kefere ve'l-Mulhidîn Ebü'Muzaffer Yusuf bin Muhammed Nasır Emirü'l-Mü'minin Halledâllâhû mülkehu ve e'azze ensârehû ve Â'la Rayetehu ve enara burhanahu vileyet El-Fakir ilâ Rahmetillâhi Ömer ibn Ahmed ibn Hablullah İbn Muhammed ibn Ebi Cerâde Gaferallâhû lehü velivalideyye ve'li-cemii el-Müslimin fî sene Selase ve erbâin ve sittimi'e (643/1245).

\section{Türkçe Tercümesi:}

Bismillahirrahmanirrahim, bu mihrap efendimiz, sultan, adil kral, vefalı, murabit, desteklenen, zafere ulaşan, mübarek, yardım eden, dünya ve dinin salahı, İslam ve Müslümanların sultanı, mazlumların haklarını zalimlerden alan, dünyada adaleti yükselten, kafirleri ve dinsizleri zayıf düşüren, müminlerin emirini destekleyen, Ebî Muzaffer Yusuf bin Muhammad'in zamanında yenilenmiştir. Allah zikrini daim etsin, onu destekleyenleri aziz kılsın, sancağını yükseltsin, hüccetini anlamasını nasip etsin. Fakirin vilayeti, Allah rahmetine, Omar bin Ahmad bin Habli'l-ah ibn Muhammad ibn Ebî Cerâde, Allah onu, annemi ve babamı ve tüm Müslümanları affetsin. 643 yılinda. 


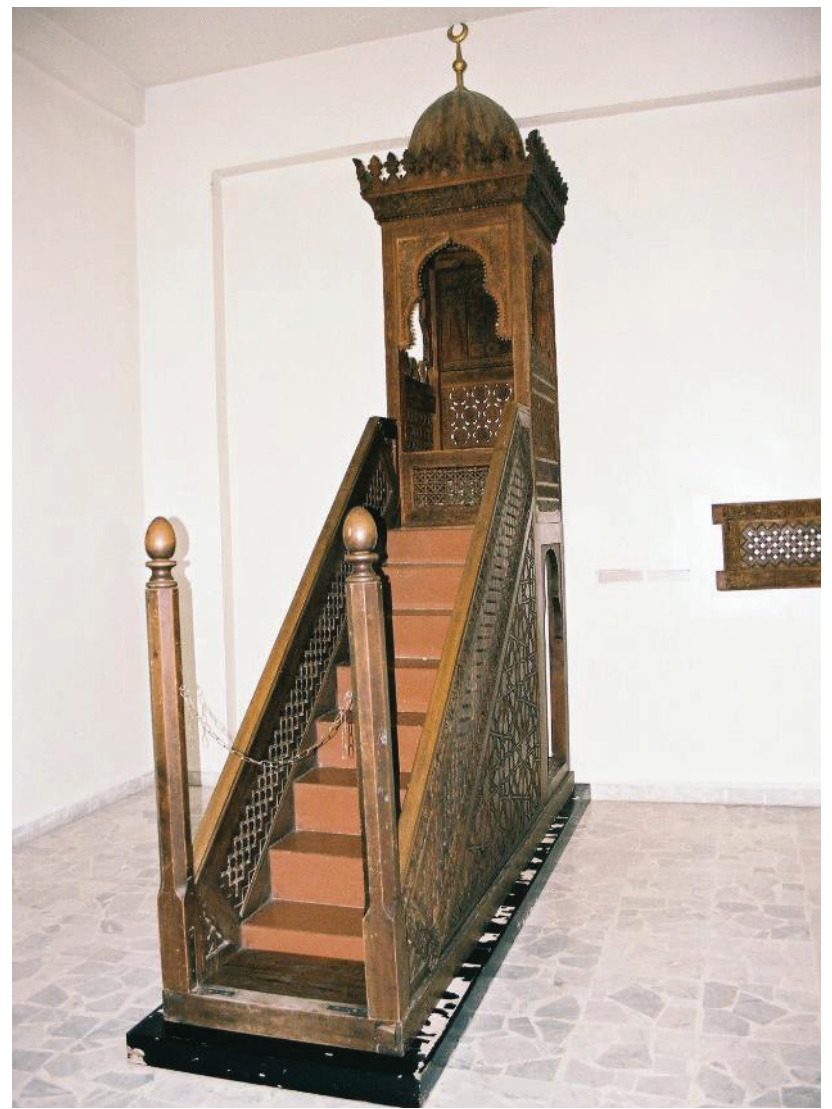

G. 11: Hama Müzesi Hama Ulu Cami Minberi (R. Aykaç, 2007)

Minberin içi, kafes tekniğinde yapılmış eşkenar dörtgenlerden gelişen geometrik süslemelere sahiptir. Korkuluğun altındaki üçgen biçiminde yan aynalıkların yüzeyi on iki kollu yıldızlardan gelişen geometrik bezemeye sahiptir. Geçit/dolap bölümü kemerli olup üzerindeki köşk korkuluğu iki bölüme ayrılmıştır. Köşk korkuluğu etrafi palmet-rumilerle bitkisel bezemeli, alt kısım kafes tekniğinde yapılmış eşkenar dörtgenlerle, üst ise yine kafes tekniğinde sekizgenlerle tezyin edilmiştir. Bunların içleri kabaralarla ve araları dört kollu yıldızdan oluşan geometrik motifler ile bezenmiştir. Köşk bölümü, üç dilimli kemer formunda olup üzeri kubbe ile örtülüdür ve hilal biçiminde alemle sonlanmaktadır. Kemer içleri büyüklü küçüklü palmet tepelikleriyle hareketlendirilmiştir. Köşk kemer köşeliği ve çerçevesi birbirine geçmeli rumilerle bitkisel bezemeli olup üst kısım celi sülüs hatlı yazı kuşağı ve palmetlerle nihayetlenmektedir. 


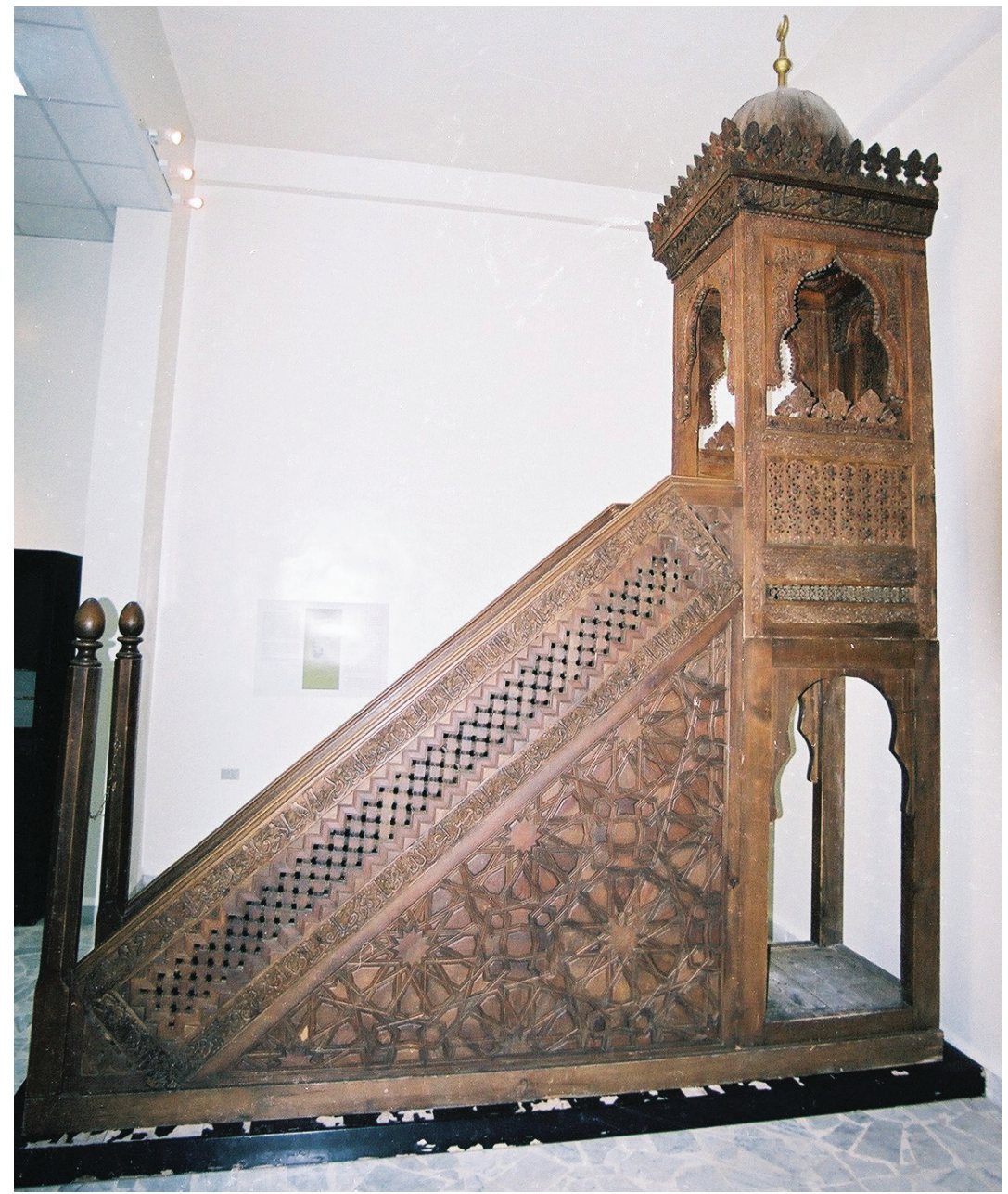

G. 12: Hama Müzesi Hama Ulu Cami minberinin yandan görünüşü (R. Aykaç, 2007) 


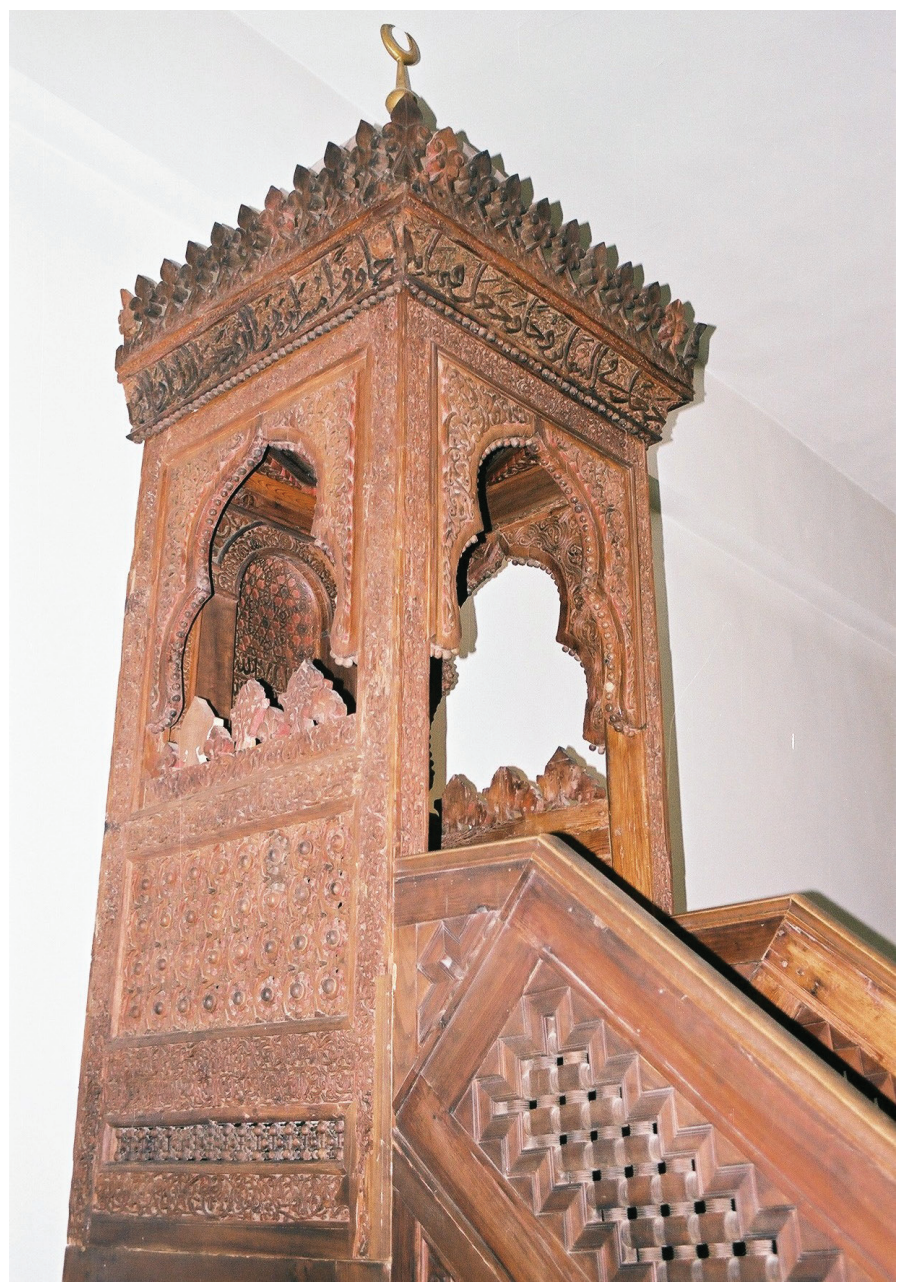

G. 13: Hama Müzesi Hama Ulu Cami minberinin köşk bölümü (R. Aykaç, 2007)

\section{Rakka Müzesi}

Osmanlı Devleti'nin 1861 yılında hükümet binası olarak inşa ettirdiği yapı 1981 y1lında Rakka Müzesi olarak hizmet vermeye başlamıştır. Ekim 2017'den sonra bina tamir edilmeye başlanmış ve 2018'den sonra müzede kalan eserler korunmaya çalış1lmaktadır.

Müzede özellikle Tell Sabi Abyad, Tell Bi'a, Tell Chuera, Tell Munbaqa gibi höyüklerde yapılan kazılardan çıkarılan eserler sergilenmekteydi. Ayrıca müze, Roma ve Bizans dönemlerine ait çeşitli eserler ile İslami döneme ait 7000 eseri de bünyesinde barındırmaktaydı. İki katlı müzenin birinci katında Antik dönem eserleri ve modern sanat; ikinci katta İslami dönem eserleri yer almaktaydı. Müzede H 553 / M 1158 tarihli kufi kitabe ve parçaları, H 1094/ M 1683 tarihli Osmanlı Türkçesi ile yazılmış celi ta'lik kale kitabesi, Kasru'l-Benât seramikleri ve cam eşyalar sergilenmekteydi. 


\subsection{Rakka Ulu Camii Alçı Süsleme Parçaları}

Rakka Müzesi'nde, Rakka Ulu Camii'ne ait alçı plakalar sergilenmektedir. Alçı plakalar kalıplama tekniğiyle yapılmış, bitkisel bezemelerle tezyin edilmiştir. Emeviler ve Abbasiler döneminde dini ve sivil mimaride bolca örnekleri görülen alçı süslemeler, Zengiler döneminde Rakka Ulu Camii'nde de uygulanmıştır.

Rakka Ulu Camii'nin giriş cephesi ve minaresi dışındaki bölümleri günümüzde temel seviyesine kadar yıkık durumdadır. Müzenin kurulmasından sonra caminin alçı süslemeleri buraya taşınmıștır.

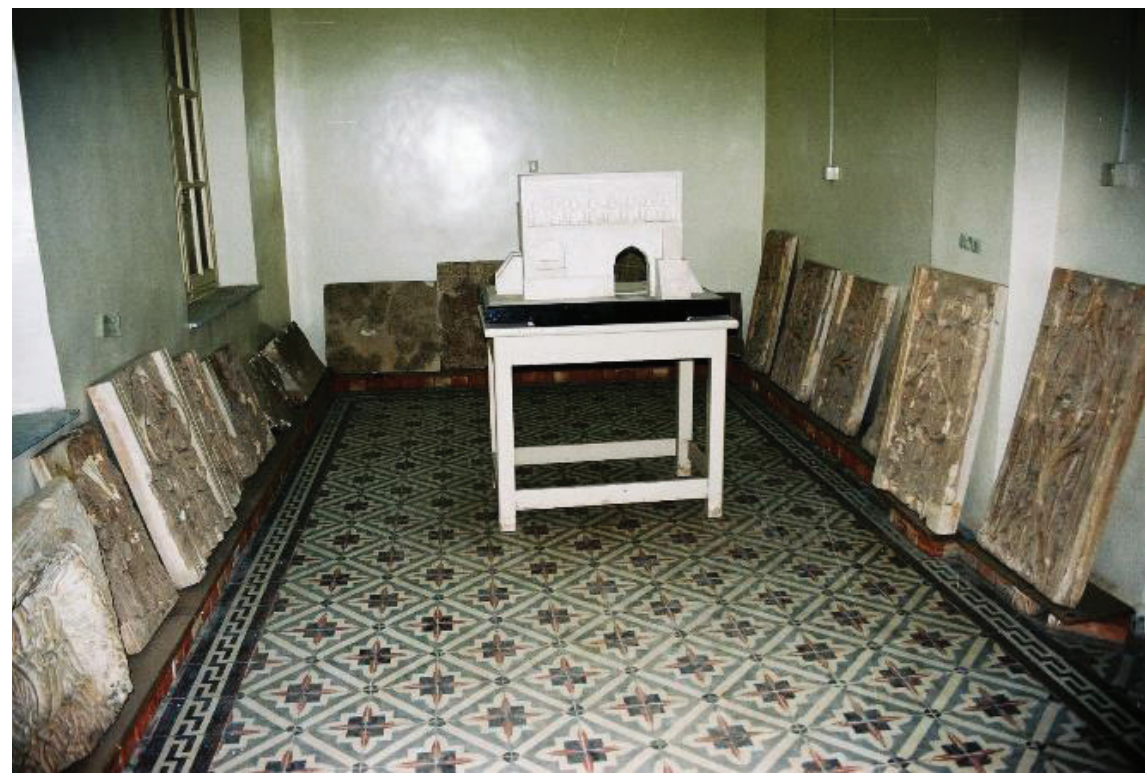

G. 14: Rakka Müzesi Rakka Ulu Camii Alçı Süsleme Parçaları (R. Aykaç, 2007)

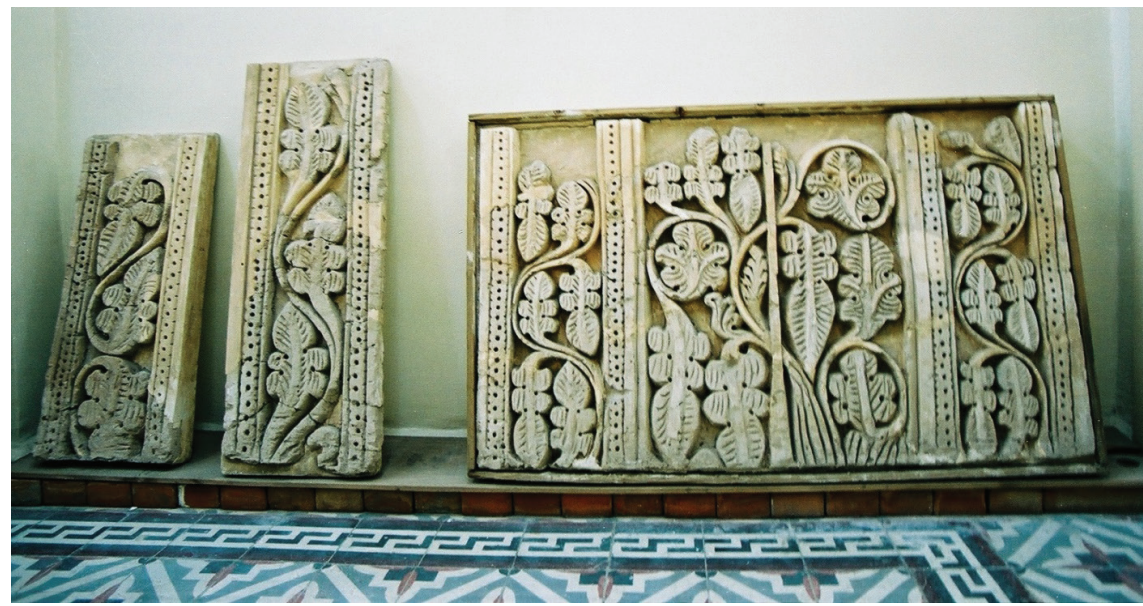

G. 15: Rakka Müzesi Rakka Ulu Camii Alçı Süsleme Parçalarından ayrıntı (R. Aykaç, 2007) 


\section{Değerlendirme}

Suriye'nin en büyük müzesi olan ve her bölgeden pek çok eserin bulunduğu Şam Milli Müzesi, Afemia kazısından çıkan eserlerin yer aldığı Madik'de Afemia (Yavuz Sultan Selim Hanı) Müzesi, bölgeden çıkan mozaiklerin korunduğu Maarra Mozaik (Murad Çelebi Hanı) Müzesi, Humus Zehravi Evi Etnografya Müzesi, Lazkiye Tütün Hanı Lazkiye Müzesi, Tartus Müzesi, Rakka Müzesi, Halep Müzesi, Halep Canbolat Evi Müzesi, Hama Müzesi ve özel kişilere ait müzeler Suriye’nin kültür hazinelerini barındırmaktadır.

Zengiler döneminde yaşamış Hüseyin b. Hasan el- Şükri’nin Halep Müzesi'nde bulunan sandukası Halep taşındandır. Sandukanın gövdesine çiçekli kufi hatlı Ayetel Kürsi hakkedilmiştir. Sanduka biçim ve süsleme açısından Selçuklular dönemi özelliklerini yansıtmaktadır. Halep'te sanduka biçiminde mezar yapma geleneği Osmanlı dönemi sonuna kadar devam etmiştir. Halep Mevlevihanesi'nin haziresinde de Osmanlı dönemine ait pek çok benzer mezar taşı bulunmaktadır' .

Aslan, Türklerde kutsal hayvan olup güç, kuvvet, devlet, hükümdarlık sembolüdür. Aynı zamanda aslan figürünün koruyucu tılsım olduğuna inanılmaktadır. Aslan, Sultan Baybars'ın isminin anlamıdır ayrıca onun Moğol ve Haçlılar karşısındaki gücünü temsil ettiğginden Sultan tarafindan bu figür arma olarak da kullanılmıştır ${ }^{10}$. Aslan figürü pek çok sivil yapıyı ve eseri bezemede kullanılmıştır. Astrolojide Güneş, Aslan burcunu temsil etmektedir. Bu sebeple Aslan ve Güneş temalı motiflerin yaygın kullanımı bulunmaktadır. Selçuklular, Zengiler ve Memlükler döneminde özellikle kalelerde, anıtsal yapılarda bu motiflerden oluşan kabartmalara yer verilmiştir. Halep dış kale surlarından getirilen karşılıklı betimlenen aslan kabartması da şehri düşmandan ve kötülüklerden koruyan bir özelliğe sahip olmalıdır. Benzer örnekleri Halep İç Kale ${ }^{11}$, Şam Kalesi, Madik Kalesi ve Diyarbakır surlarında ${ }^{12}$ görmek mümkündür.

Eyyûbî Sultanı için Harranlı ahşap ustası tarafından H 643/ M 1245 yılında yapılan mihrap, müzenin nadide eserleri arasındadır. Ahşap mihrapların güzel bir örneği olan eser; celi sülüs yazısı, Zengi düğümlü alınlığı, bitkisel ve geometrik süsleme özellikleriyle Selçuklu geleneğini yansıtmaktadır. Özellikle Zengi düğümü formu bölgede Zengiler'den sonra da mihrap, minber, taç kapı gibi yerlerde sevilerek kullanılmıştır.

İlk olarak MS 9. yüzyılda Abbasiler döneminde Samarra ve Basra'da İslam çömlekçileri tarafından lüster sırlı seramikler üretilmiştir. Bu seramiklerin en güzel örnekleri

9 Ali Boran, "Halep Mevlevihanesindeki Mezar Taşları", Uluslararası Türk-İslam Mezar Taşları Kongresi I, (Aydın: Yeni Fikir Dergisi Yayınları, 2018), 145, 147.

10 Yaşar Çoruhlu, Türk Sanatında Hayvan Sembolizmi (İstanbul: Seyran Kitap, 1995), 113; Hayrunnisa Turan, "Kudüs’teki Memlûk Türk Devleti Armaları ('Renk'ler)”, Belleten 83/298 (2019), 892-893.

11 Ali Boran, "Halep İç Kalesi”, Uluslararası Türk Sanatları Sempozyumu ve Sanat Çalıştayı I (Konya: Anka Basım Yayın, 2012), 215.

12 Ali Boran ve Razan Aykaç, "Yeni Araştırmalar Bağlamında Diyarbakır Kalesi”, Selçuk Üniversitesi Sosyal Bilimler Dergisi 42 (2019), 273-282. 
Mısır'ın başkenti Fustat'ta Fatimi Hanedanı döneminde, ardından 12.-15. yüzyılda Suriye'de ve 12.-17. yüzyılda İran'da üretilmiştir ${ }^{13}$. İnsan figürleriyle temsil edilen gezegen ve burç işaretleri mimaride olduğu gibi madeni ve seramik eserlerde de yaygın bir ikonografik motif olarak kullanılmıştır ${ }^{14}$. Halep Müzesi'ndeki altın parıltısı içeren lüster tekniğinde yapılan seramik; merkezinde yer alan Güneş betimlemesi ay yüzlü, badem gözlü olup Uygur tipindedir ve bu betimleme Orta Asya etkileşimini yansıtmaktadır. 13. yüzyıl Eyyûbîler dönemine ait bu eserin hem teknik özellikleri hem de üzerindeki kompozisyonu bunun özel üretim olduğuna işaret etmektedir.

Halep Müzesi’nde vitrinde tek renk sır, sıraltı, lüster tekniklerinde yapılmış tabak, kâse, testi, matara gibi eserler teşhir edilmektedir. Bunlar arasında yer alan açık formda seramik kap örneği (tören kabı) ağızdan gövdeye bağlanan çok kulplu olup turkuaz tek renk sırlıdır. Bu kabın benzer örneği Silifke Kalesi kazısında çıkarılmıştır ${ }^{15}$ ayrıca Urfa Müzesi'nde İslam eserleri seksiyonunda sergilenmektedir. Halep Müzesi'ndeki eserler arasında yer alan turkuaz tek renk sırlı Tip-1a. Basık Elips Gövdeli Kandil ile Tip-1b.2.Basık Küre Gövdeli ve Ikiden Fazla Fitil Delikli Kandil ${ }^{16}$ örneklerinin benzerleri ise Anadolu'daki pek çok kazıda ortaya çıkarılmıştır. Tören kabı ile seramik kandil örneklerinin form, teknik, sır rengi dikkate alındığında 13. yüzyıl Selçuklu dönemi özelliklerini yansıttı̆̆ı anlaşılmaktadır.

Memlüklü Sultanı Kayıtbay’a (1423-1496) ait olan madalyon biçimindeki bani kitabe parçası, yazı ve istif açısından Sultan Kayıtbay dönemi özelliğini yansıtmaktadır. Büyük bölümü günümüze ulaşmayan kitabe, Halep dış kale surlarına ait olmalıdır. Memlükler döneminde başta kale kapıları ve burçlar olmak üzere bu türden kitabeler yaygın olarak kullanılmaktadır ${ }^{17}$. Bu kitabe örneklerinin benzerleri Şam Kalesi, Ankara Etnografya Müze bahçesinde sergilenen Urfa Kalesi'ne ait kitabe parçalarında ve Gaziantep İç Kalesi'nde görülmektedir.

Asker kökenli olan Memlüklü hanedanları savaş aletleri ve zırhlara ayrı bir önem vermişlerdir. Bu savaş aletlerinin üzerlerindeki süslemeler Selçuklu geleneğinin devamı olarak dönemin özellikleriyle harmanlanmıştır. Sultanlar ve komutanlara göre ayrıntıda farklılıklar olmasına karşılık genel olarak miğfer, zırh, kalkan ve topuzda süsleme ve dua içerikli yazılar yer almaktadır ${ }^{18}$. Aynı dönem özelliğini taşıyan savaş aletleri ve giysilerin benzeri Mersin Deniz Müzesi’nde sergilenmektedir.

13 David Talbot Rice, Islamic Art (Singapore: G.S. Graphics, 1993), 38, 132; Alan Caiger Smith, Lustre Pottery: Technique, Tradition and Innovation in Islam and the Western World (Gentle Breeze Publishing: 2001).

14 Ülker Erginsoy, İslam Maden Sanatının Gelişmesi (İstanbul: Kültür Bakanlığı Yayınları, 1978), 130; Esin Atıl, W.T. Chase ve Paul Jett, Islamic Metal Work (Washington: Smithsonian Institution Press, 1985), 150, 151; Gönül Öney, Anadolu Selçuklu Mimari Süslemesi ve El Sanatları (Ankara: İş Bankası Kültür Yayınları, 1992), 36.

15 Ali Boran ve Razan Aykaç, Silifke Kalesi Kazı Buluntuları (2010-2020), (İstanbul: Ege Yayınları, 2021$), 126$. 16 Aykaç, Konya Karatay Müzesindeki Anadolu Selçuklu Dönemi Seramik Kandiller, 25, 65.

17 Meinecke, Die Mamlukische Architektur in Agypten und Syrien, Tafel 70/a.

18 Altan Çetin, Memlük Devletinde Askeri Teşkilât (İstanbul: Eren Yayıncılık, 2007). 
Hama Müzesi'nde sergilenen Hama Ulu Cami Minberi H 559/ M 1163-1164 y1lında Nureddin Zengi tarafından yaptırılan iki minberden biridir. Diğer minber Mescidi Aksa için yaptırılmıştır. Hama Müzesi'nde sergilenen minber Zengiler döneminin en güzel kündekâri tekniğindeki minber örneklerinden biridir. Konya Alaaddin Camisi'nin minberi de aynı üslup ve süsleme özelliklerine sahiptir ${ }^{19}$.

Rakka Müzesi'ndeki Rakka Ulu Camii'nden getirilen alçı süslemeler bölgede görülen nadide parçalardır. Bölgede sevilen, tercih edilen bu malzemenin dayanıksız olması süslemelerin pek çoğunun günümüze kadar ulaşmasına engel olmuştur. Özellikle Erken İslam Sanatı sivil mimarisinde önemli bir bezeme unsuru olan alçı, 9. yüzyılda Bağdat'ın kuzeyinde Türk askerler için kurulan Samarra şehrinde gelişmiş ve etkileri doğudan batıya geniş coğrafyada yüzyıllar boyu sürmüştür ${ }^{20}$. Samarra'da kazılar sonucu ortaya çıkan alçı süslemeler, Herzfeld tarafından I. II. ve III. stiller (A, $\mathrm{B}, \mathrm{C})$ olmak üzere üç grupta değerlendirilmiştir ${ }^{21}$. Rakka Müzesi örnekleri Samarra A üslubuna yakındır. Alçı süslemelerin benzerleri Selçuklular dönemine tarihlendirilen ve Van Müzesi'nde sergilenen Van Ulu Cami alçı süslemeleridir.

\section{Sonuç}

Halep, Hama ve Rakka müzelerinde Türk-İslam dönemine ait yüzlerce eser sergilenmektedir. Bu eserlerden Halep Müzesi'ndeki Hüseyin b. Hasan el- Şükri'nin sandukası, Aslan Kabartmalı Mimari Plastik, Haleviye Medresesi Mihrabı, Güneş Motifli Lüster Kâse, Seramik Kaplar, Memlüklü Armalı Mimari Plastik, Sultan Kayıtbay’a Ait Kitabe Parçası; Hama Müzesi'nden Hama Ulu Cami Minberi; Rakka Müzesi'nden Alçı Süsleme örnekleri Selçuklular, Zengiler, Eyyûbîler ve Memlükler dönemine ait bölgedeki en değerli eserlerdendir. Bu müzelerin tekrar ziyarete açılması, tüm kıymetli eserlerin incelenerek bilim dünyasına tanıtılması temennimizdir.

Hakem Değerlendirmesi: Dış bağımsız.

Çıkar Çatışması: Yazar çıkar çatışması bildirmemiştir.

Finansal Destek: Yazar bu çalışma için finansal destek almadığını beyan etmiştir.

Teşekkür: Halep, Hama ve Rakka müzelerindeki 10 günlük çalışmamızda her türlü kolaylığı sağlayan müze müdürlerine teşekkür ederim.

Peer-review: Externally peer-reviewed.

Conflict of Interest: The author has no conflict of interest to declare.

Grant Support: The author declared that this study has received no financial support.

Acknowledgment: I would like to thank the director of the museums who provided great convenience during our 10-day work in the Aleppo, Hama, and Raqqa museums.

19 Ali Boran, Anadolu'daki İç Kale Cami ve Mescidleri (Ankara: Türk Tarih Kurumu Basımevi, 2001), 24-33.

20 Öney, Anadolu Selçuklu Mimari Süslemesi ve El Sanatları, 83.

21 Abdullah Karaçağ, "Alçı Sanatı”, Anadolu Selçukluları ve Beylikler Dönemi Uygarlı̆̆ (Mimarlık ve Sanat) 2, ed. Ali Uzay Peker ve Kenan Bilici (Ankara: T.C Kültür ve Turizm Bakanlığı Yayınları, 2006), 494. 


\section{Kaynakça/References}

Abdülkâdir, Er- Reyhâvî. El I'mâratü'l Arabiyyetü'l İslâmiyye, Hasâisuhâ ve Âsâruhâ fì Suriye. Dımaşk: y.y, 1999.

Allen, Terry. "Madrasah al-Halawiyah". In Ayyubid Architecture. Occidental, CA: Solipsist Press, 2003

At1l, Esin, W. T. Chase ve Paul Jett. Islamic Metal Work in the Freer Gallery of Art. Washington: Smithsonian İnstitution Press, 1985.

Aykaç, Razan. Konya Karatay Müzesindeki Anadolu Selçuklu Dönemi Seramik Kandiller. Konya: Palet Yayınları, 2017.

Aykaç, Razan. Silifke Kalesinin Kazılar Sonucu Ortaya Çıkan Yerleşim Dokusu. İstanbul: Ege Yayınları, 2021.

Aykaç, Razan. Türkiye Müzelerindeki İslami Dönem Seramik Kandiller. İstanbul: Ege Yayınları, 2021.

Berchem, Max Van. Materiaux pour un Corpus Inscriptionum Arabicarum, XLV. Kahire: Fransiz Arkeoloji Enstitüsü Yayınları, 1920-1923.

Boran, Ali ve Razan Aykaç. "Yeni Araştırmalar Bağlamında Diyarbakır Kalesi”. Selçuk Üniversitesi Sosyal Bilimler Dergisi 42 (2019), 273-282.

Boran, Ali ve Razan Aykaç. Silifke Kalesi Kazı Buluntuları (2010-2020). İstanbul: Ege Yayınları, 2021.

Boran, Ali. Anadolu'daki Iç Kale Cami ve Mescidleri. Ankara: Türk Tarih Kurumu Basımevi, 2001.

Boran, Ali. "Hama'daki Tarihi Su Dolapları ve Kemerler". Su Medeniyeti Sempozyumu, Konya: Konya Büyükşehir Belediyesi (2010), 502-515.

Boran, Ali. "Halep İç Kalesi”. Uluslararası Türk Sanatları Sempozyumu ve Sanat Çalıştayı 1, Konya: Anka Basım Yayın (2012), 211-218.

Boran, Ali. "Halep Mevlevihanesindeki Mezar Taşları”. Uluslararası Türk-İslam Mezar Taşları Kongresi 1, Aydın: Yeni Fikir Dergisi Yayınları (2018), 124-149.

Çetin, Altan. Memlük Devletinde Askeri Teşkilât. İstanbul: Eren Yayıncılık, 2007.

Çobanoğlu, Ahmet Vefa. "Zengiler, (Mimari)”. TDV İslâm Ansiklopedisi, c. 44, İstanbul: Türkiye Diyanet Vakfi Yayınları (2009), 272-274.

Çoruhlu, Yaşar. Türk Sanatında Hayvan Sembolizmi. İstanbul: Seyran Kitap, 1995.

Erginsoy, Ülker. İslam Maden Sanatının Gelişmesi. İstanbul: Kültür Bakanlığı Yayınları, 1978.

Gonnella, Julia. Das Aleppo Zimmer Museum Für Islamiche Kunst. Berlin: Museum für İslamische Kunst, 1996.

Hadjar, Abdallah. Historical Monuments of Aleppo. Aleppo: Automobile and Touring Club of Syria (A.T.C.S), 2000.

İnal, Güner. Türk İslam Maden Sanatı. Ankara: Hacettepe Üniversitesi-Teksir Bask1, t.y.

Karaçağ, Abdullah. “Alçı Sanatı”. Anadolu Selçukluları ve Beylikler Dönemi Uygarlı̆̆ (Mimarlık ve Sanat) 2. Ed. Ali Uzay Peker ve Kenan Bilici, Ankara: T.C. Kültür ve Turizm Bakanlığı Kütüphaneler ve Yayımlar Genel Müdürlüğü (2006), 493-505.

Meinecke, Michael. Die Mamlukische Architektur in Agypten und Syrien. Glückstadt: Verlag J.J. Augustin, 1992. 
Öney, Gönül. Anadolu Selçuklu Mimari Süslemesi ve El Sanatları. Ankara: İş Bankası Kültür Yayınları, 1992.

Rice, David Storm. "Studies in Islamic Metal Work". Bulletin of the School of Oriental and African Studies 14 (1952), 564-578.

Rice, David Talbot. Islamic Art. Singapore: G.S. Graphics, 1993.

Smith, Alan Caiger. Lustre Pottery: Technique, Tradition and Innovation in Islam and the Western World, Gentle Breeze Publishing, 2001.

Turan, Hayrunnisa. "Kudüs’teki Memlûk Türk Devleti Armaları ('Renk'ler)”. Belleten 83/298 (2019): 887-912.

Uluçam, Abdüsselam. "Suriye Mimari”. TDV İslâm Ansiklopedisi, c. 37, İstanbul: Türkiye Diyanet Vakfi Yayınları (2009), 559-565.

"Madrasah al-Hâlawîyah". Erişim 2 Ağustos 2005.

http://www.sonic.net/ tallen/palmtree/ayyarch/ch2.htm\#alep.mhal 